\title{
PENGARUH MOTIVASI BELAJAR TERHADAP HASIL BELAJAR SISWA KELAS VIII DI SEKOLAH MENENGAH PERTAMA YWKA PALEMBANG
}

\author{
Trisni Hartina ${ }^{1}$, Susun Nayati Nasution ${ }^{2}$ \\ SMP YWJA Palembang ${ }^{1}$ \\ Email : trisnihartina@gmail.com \\ SMP YWJA Palembang ${ }^{2}$ \\ Email: susunnayatinasution@gmail.com
}

\begin{abstract}
ABSTRAK
Tujuan penelitian ini adalah untuk mengetahui pengaruh motivasi belajar terhadap proses belajar di lingkungan kelas siswa. Dalam penelitian ini menggunakan metode eksperimen. Teknik pengumpulan data dalam penelitian ini menggunakan tes Observasi, kusioner (angket), dan wawancara. Teknik pengumpulan data pada penelitian ini menggunakan Observasi, Dokumentasi dan Angket. Teknis analisis data dalam penelitian ini menggunakan rumus uji $t$. Berdasakan hasil penelitian, analisis data, pengujian hipotesis yang dilakukan peneliti serta hasil pembahasan yang didapat, maka dapat disimpulkan bahwa: 1) Ada pengaruh motivasi belajar terhadap hasil belajar siswa di SMP YWKA Palembang 2019/2020 diterima. 2) Ho Terima jika t hitung6,369 < $t$ tabel 1,683 maka Ha ditolak.
\end{abstract}

Kata Kunci: Motivasi Belajar Siswa, Bimbingan Konseling

THE INFLUENCE OF STUDY MOTIVATION ON THE LEARNING OUTCOMES OF GRADE VIII STUDENTS IN THE FIRST YWKA PRIVATE VOCATIONAL SCHOOL PALEMBANG

\begin{abstract}
The purpose of this study was to see the effect of learning motivation on the learning process in the classroom environment of students. In this study using an experimental method. Data techniques in research using observation tests, questionnaires (questionnaires), and interviews.Technique data in research using observation, documentation and questionnaires. The data analysis technique in this study used the t test formula. Based on the results of research, data analysis, hypothesis testing conducted by researchers and the results of the discussion obtained, it can be ignored that: 1) There is an effect of learning motivation on student learning outcomes at SMP YWKA Palembang 2019/2020. 2) Ho Accept if t count 6,369<t table 1,683 then Ha is rejected.
\end{abstract}

Keywords: Student Learning Motivatoin, Guidance Counseling 


\section{PENDAHULUAN}

Setiap bentuk aspek kehidupan manusia baik pribadi, keluarga maupun dalam berbangsa dan bernegara yang sedang membangun banyak ditentukan oleh kemajuan. Pendidikan merupakan usaha sadar untuk menumbuhkan potensi dasar manusia melalui melalui kegiatan pengajaran.

Maka bimbingan konseling merupakan suatu proses untuk membantu siswa dalam mengembangkan dirinya sehingga mampu menghadapi setiap perubahan yang terjadi. Secara garis besar proses bimbingan dapat terjadi dalam lingkungan bimbingan. Lingkungan bimbingan adalah tempat seseorang memperoleh pendidikan secara langsung atau tak langsung, oleh karena itu lingkungan bimbingan ada yang bersifat social dan material.

Pada perkembangan ilmu dan tehnologi yang semakin pesat dan arus globalisasi juga semakin hebat maka munculah persaingan di bidang pendidikan. Salah satu cara yang ditempuh adalah melalui tingkat mutuh pendidikan. Dalam rangkah meningkatkan mutu pendidikan tersebut, pemerintah melakukan perbaikan-perbaikan agar mutuh pendidikan meningkat diantaranya pebaikan kurukilum, sumber daya manusia, sarana dan prasarana. Perbaikan-perbaikan tersebut tidak ada artinya tanpa dukungan dari guru dan keikut sertaan dari bimbingan konseling, serta orang tua siswa dan masyarakat linkungan sekitarnya dalam mencapai tujuan meningkatkan mutu pendidikan.

Apabila membahas tentang mutu pendidikan maka tidak lepas dari kegiatan belajar menganjar. Kegiatan belajar mengajar di sekolah merupakan kegiatan yang paling fundamental, ini berarti bahwa berhasil tidaknya pencapaian tujuan pendidikan antara lain berpengaruh pada bagaimana proses belajar yang dialami siswa selaku anak didik.

Hasil belajar dapat dilihat dari terjadinya perubahan hasil masukan pribadi berupa motivasi dan harapan untuk berhasil.Masukan itu berupa rancangan dan pengolahan motivasional yang tidak berpengaruh langsung terhadap besarnya usaha yang dicurahkan oleh siswa untuk mencapai tujuan belajar.Perubahan itu terjadi pada seseorang dalam kecakapan manusia yang berupa penguasaan ilmu pengetahuan dan ketrampilan yang diperoleh melalui usaha yang sungguh-sungguh dilakukan dalam waktu tertentu.yang relatif lama. 
Hasil belajar yang diharapkan biasanya berupa prestasi belajar yang baik atau optimal. Namun dalam pencapaian hasil belajarnya yang baik masih saja mengalami kesulitan dan prestasi yang didapat belum dapat dicapai secara optimal.Dalam peningkatan hasil belajar siswa di pengaruhi banyak faktor, salah satunya yakni motivasi belajar.

Dalam motivasi belajar terkandung adanya cita-cita atau aspirasi siswa dengan demikian diharapkan siswa mendapat motivasi belajar sehingga mengerti dengan apa yang menjadi tujuan dalam belajar. Disamping itu keadaan siswa yang baik dalam belajar akan menyebabkan siswa itu bersemangat dalam belajar dan mampu menyelesaikan tugas dengan baik. Kebalikannya dengan siswa yang sedang sakit ia tidak mempunyai gairah dalam belajar (Mujiono, 2002:98).

Motivasi bukan saja penting karena menjadi faktor penyebab belajar namun juga memperlancar belajar dan hasilbelajar. Seorang guru bimbingan konseling harus selalu mengetahui kapan siswa perlu diberi motivasi selama proses belajar, sehingga aktivitas belajar akan berlangsung lebih menyenangkan, arus komunikasi lebih lancar, menurunkan kecemasan siswa, meningkatkan kreativitas dan aktivitas belajar. Pembelajaran yang di ikuti oleh siswa yang termotivasi akan benar-benar menyenangkan, terutama bagi guru. Dan siswa yang mengerjakan tugas belajar dengan perasaan termotivasi terhadap materi yang telah dipelajari mereka akan lebih bergairah dalam mengikuti proses pembelajaran tersebut.

Siswa yang bermotivasi baik dalam belajar merupakan dorongan tingkah laku secara organism untuk mencapai tujuan., maka semakin baik hasil belajar yang diperolehnya. Siswa melakukan berbagai upaya atau usaha untuk meningkatkan keberhasilan dalam belajar sehingga mencapai keberhasilan yang cukup memuaskan sebagaimana diharapkan. Disamping itu motivasi juga menopang upaya-upaya dan menjaga agar proses belajar siswa tetap jalan. Hal ini menjadikan siswa gigih dalam belajar.

Dari pengertian di atas pendidikan mempunyai peran penting dalam kehidupan manusia dan kehidupan dimasa yang akan datang. Dalam meningkatkan mutu pendidikan di butuhkan peran guru Bimbingan dan Koseling untuk membantu setiap siswa agar berkembang secara optimal. Salah satu penunjang utama nya adalah adanya motivasi belajar bagi peserta didik yang terstruktur dengan baik. 


\section{LANDASAN TEORI}

Menurut Surya (2009:103), motivasi diartikan sebagai dorongan untuk mewujudkan prilaku tertentu yang terarah pada suatu tujuan tertentu. Motivasi mempunyai karakteristik : (1) sebagai hasil dari kebutuhan, (2) terarah pada sutu tujuan (3) menopang prilaku.

Hasil belajar menurut Udin S Winataputra, (2007:110) merupakan bukti keberhasilan yang telah dicapai siswa dimana setiap kegiatan belajar dapat menimbulkan suatu perubahan yang khas. Dalam hal ini belajar meliputi keterampilan proses, keaktifan, motivasi juga prestasi belajar. Prestasi adalah kemampuan seseorang dalam menyelesaikan suatu kegiatan-kegiatan.

Saat pembelajaran berlangsung siswa mampu memberikan umpan balik terhadap guru. Sardiman (2006:100) menyatakan bahwa aktivitas belajar merupakan aktivitas yang bersifat fisik maupun mental.Dalam kegiatan belajar keduanya saling berkaitan. Aktivitas belajar dapat terwujud apabila siswa terlibat belajar secara aktif, pembelajaran akan menghasilkan suatu perubahan dan peningkatan kemampuan, penetahuan dan keterampilan pada diri siswa. Siswa mampu menggali kemampuannya dengan rasa ingin tahunya sehingga interaksi yang terjadi akan menjadi pengalaman dan keinginan untuk mengetahui sesuatu yang baru.

Menurut Purwanto (2007:28) Lingkungan sosial ialah semua orang lain yang mempengaruhi kita. Sebagai anggota masyarakat maka siswa dapat terpengaruh oleh lingkungan sekitar. Lingkungan sekitar berupa keadaan alam tempat tinggal, pergaulan sebaya dan lingkungan sekitar.Oleh karena itu lingkungan yang sehat turut mempengaruhi motivasi belajar.

Menurut Dimyati dam Mujiono (1994:89-92) ada beberapa faktor yang mempengaruhi motivasi belajar, yaitu :

a. Cita-cita atau aspirasi siswa

Cita-cita dapat berlangsung dalam waktu lama, bahkan sepanjang hayat. Cita-cita siswa untuk "menjadi seseorang" akan memperkuat semangat belajar dan mengarahkan pelaku belajar. Cita-cita akan memperkuat motivasi belajar intrinsic maupun ekstrinsik, sebab tercapainya sustu cita-cita akan mewujudkan aktualisasi diri. 


\section{b. Kemampuan belajar}

Dalam belajar dibutuhkan berbagai kemampuan. Kemampuan ini meliputi beberapa aspek psikis yang terdapat dalam diri siswa. Misalnya pengamatan, perhatian, ingatan, daya piker dan pantastis. Didalam kemampuan belajar ini, sehingga perkembangan berpikir siswa menjadi menjadi akurat. Siswa yang taraf perkembangan berpikirnya konkrit (nyata) tidak sama dengan siswa yang berpikir secara operasional (berdasarkan pengamatan yang dikaitkan dengan kemampuan daya nalarnya). Jadi siswa yang mempunyai kemampuan belajar tinggi, biasanya termotivasi dalam belajar, karena siswa seperti itu lebih sering memperoleh sukses oleh karena kesuksesan memperkuat motivasinya.

c. Kondisi Jasmani dan Rohani

Siswa adalah mahluk yang terdiri dari kesatuan psikofisik. Jadi kondisi siswa yang mempengaruhi motivasi belajar disini berkaitan dengan kondisi fisik dan kondisi psikologis. Apabila kondisi fisik dan psikologis seorang siswa baik maka akan mendapatkan hasil belajar yang baik, begitu juga sebaliknya apabila kondisi fisik dan psikologis siswa tidak baik maka akan kurang dorongan untuk melakukan kegiatan belajar sehingga akan cenderung malas hingga ahirnya berpengaruh ke hasil yang di peroleh tentunya hasil yang di peroleh akan kurang baik atau kurang memuaskan.

d. Kondisi Lingkungan

Kondisi lingkungan merupakan unsur-unsur yang datang dari luar diri siswa. Kondisi lingkungan bisa juga menjadi faktor yang dapat mempengaruhi motivasi belajar siswa. Kondisi lingkungan yang baik dan nyaman akan menumbuhkan motivasi siswauntuk berbuat yaitu belajar, dengan tumbuhnya motivasi tersebut tentu hasilbelajar siswa akan menjadi baik. Begitu juga sebaliknya apabila kondisi lingkungan kurang baik tentu akan menjadikan siswa tersebut merasa terganggu ahirnya malas untuk melakukan kegiatan belajar. Dengan malasnya siswa tersebut untuk melakukan kegiatan belajar maka sudah pasti akan berpengaruh ke hasil belajar nya.

\section{METODE PENELITIAN}

Metode penelitian adalah suatu cabang ilmu pengetahuan yang membicarakan atau mempersoalkan mengenai cara-cara melaksanakan penelitian sampai menyusun 
laporannya berdasarkan fakta-fakta atau gejala-gejala secara ilmiah.Dalam penelitian ini menggunakan metode eksperimen.Metode eksperimen adalah metode yang paling banyak dipilih dan paling produktif dalam penelitian.Bila dilakukan dengan baik, studi eksperimental menghasilkan bukti yang paling benar berkaitan dengan hubungan sebab akibat.

Sugiyono (2013:224) mengemukakan bahwa teknik pengumpulan data merupakan langkah yang paling strategis dalam penelitian, karena tujuan utama dari penelitian adalah mendapatkan data.

Terdapat beberapa metode pengumpulan data yang digunakan peneliti antara lain: Observasi, Menurut Ferdiansyah (2015:54) observasi atau pengamatan yang cermat dapat dianggap sebagai salah satu cara penelitian ilmiah yang paling sesuai dengan bidang ilmu sosial tanpa harus memerlukan biaya yang banyak, sehingga penelitian dapat dilakukan. Tahap observasi dilaksanakan oleh peneliti terhadap siswa yang di observasi (diteliti) di SMP YWKA Palembang.Adapun sasaran observasi pada penelitian ini adalah siswa kelas VIII di YWKA Palembang.

Dokumentasi

Arikunto (2010:201) menjelaskan Dokumentasi artinya barang-barang tertulis.Di dalam melaksanakan metode dokumentasi, peneliti menyelidiki benda-benda tertulis seperti buku-buku, majalah, dokumen, peraturan-peraturan, notulen rapat, catatan harian, dan sebagainya (Peneliti hanya memberikan bukti berupa photo).

Menurut Sugiyono (2018:207) analisis data merupakan kegiatan setelah data dari seluruh responden atau sumber data lain terkumpul. Kegiatan dalam menganalisis data adalah mengelompokkan data berdasarkan variabel dan jenis responden, menyajikan data tiap variabel yang diteliti, melakukan perhitungan untuk menjawab rumusan masalah dan melakukan perhitungan untuk menguji hipotesis yang telah diajukan. Teknis analisis data dalam penelitian ini digunakan untuk membuktikan hipotesis penelitian.

Teknik Analisis Data yang dilakukan oleh peneliti yaitu dengan uji t untuk menguji hipotesis apakah ada tidaknya pengaruh layanan informasi dengan rumus sebagai berikut:

$$
t=\frac{M d}{\sqrt{\frac{\sum x^{2} d}{n(n-1)}}} \quad \text { (Arikunto 2010:125) }
$$




\section{HASIL PENELITIAN DAN PEMBAHASAN}

Penelitian ini dilaksanakan di SMP YWKA Palembang, yang berlamatkan di Jalan Kimarogan No.280, RW.3, Ogan Baru, Kec. Kertapati, Kota Palembang. Pada pertemuan pertama peneliti memberikan maksud dan tujua pada kelas eksprimen bahwa saya disini ingin melakukan penelitian, setelah itu peneliti melakukan pembelajaran pada hari selasa depan. Pada pertemuan kedua peneliti mulai memberikan materi yang akan diajarkan kepada siswa yang dimana peneliti mulai memberikan materi dan pembagian kelompok supaya saling membantu dan memberikan motivasi semangat belajar, mulailah pembelajaran itu diawali peneliti memberikan motivasi kepada siswa, pendidikan adalah senjata paling mematihkan di dunia, karna dengan pendidikan anda dapat mengubah dunia, setelah itu peneliti langsung menjelaskan materi tentang kenakalan remaja setelah selesai menjelaskan peneliti mulai bertanya kepada siswa apakah sudah paham apa yang dijelaskan oleh peneliti kalau belum paham silahkan bertanya jawaban siswa sudah paham kalau sudah paham peneliti memberihkan tugas kepada siswa apakah sudah selesai atau belum tugasnya dan waktu sudah mau bel untuk jam berikutnya dan jawaban siswa belum maka peneliti jawab minggu depan. Pada pertemuan ketiga siswa sudah selesai menjawab soal yang diberikan minggu kemarin hingga mulailah sesi tanya jawab maka siswa disana mulai berdiskusi mengenai jawaban mereka dan saling memberihkan motivasi untuk maju berani menjawab soal, mereka saling beradu argumen bahwa jawaban merekalah yang benar maka peneliti mulai menangai diskusi mereka setelah diskusi peneliti meminta lember jawaban siswa, pada pertemuan keempat mulailah peneliti memberikan angket kepada siswa setelah selesai memberikan angket peneliti menunggu jawaban mereka setelah selesai peneliti langsung kluar dari kelas.

Pada pertemuan pertama peneliti memberikan maksud dan tujuan pada kelas kontrol bahwa saya disini ingin melakukan penelitian, setelah itu peneliti melakukan pembelajaran pada hari selasa depan. Pada pertemuan kedua peneliti mulai memberikan materi yang akan diajarkan kepada siswa yang dimana peneliti mulai memberikan materi mulailah pembelajaran setelah itu peneliti langsung menjelaskan materi tentang kenakalan remaja setelah selesai menjelaskan peneliti mulai bertanya kepada siswa apakah sudah paham apa yang dijelaskan oleh peneliti kalau belum paham silahkan bertanya jawaban siswa sudah paham kalau sudah paham peneliti memberihkan tugas 
kepada siswa apakah sudah selesai atau belum tugasnya dan waktu sudah mau bel untuk jam berikutnya dan jawaban siswa belum maka peneliti jawab minggu depan. Pada pertemuan ketiga siswa sudah selesai menjawab soal yang diberikan minggu kemarin hingga mulailah sesi tanya jawab maka siswa disana mulai mengumpulkan tugas yang diberihkan maka peneliti langsung mengoreksi jawaban siswa, pada pertemuan keempat mulailah peneliti memberikan angket kepada siswa setelah selesai memberikan angket peneliti menunggu jawaban mereka setelah selesai peneliti langsung keluar dari kelas.

1. Ada Pengaruh Pengaruh Motivasi Belajar Terhadap Hasil Belajar Siswa di SMP YWKA Palembang 2019/2020 Diterima.

Hasil belajar siswa dua hal yang saling mempengaruhi. Dimana dalam hal pembelajaran yang peneliti terapkan pada kelas Eksprimen pada siswa nya semangat belajar karna setelah diberikan motivasi siswa aktif dalam belajar. Motivasi belajar disini sudah didapatkan karna dalam proses belajar mengajar siswa saling memberikan semangat dalam belajar baik itu membuat kelompok pembelajaran supaya mereka saling menukar ilmu untuk memudahkan mereka belajar misalkan dalam mengerjakan soal yang diberihkan guru atau tugas mereka tidak usah takut akan tidak bisa mengerjakan tugas karna mereka sudah bisa menjawab pertanyaan yang diberikan oleh guru dan dampaknya siswa tidak akan telat hadir ke sekolah, hadir tepat waktu, absennya bagus akibat mereka saling memotivasi untuk saling semangat dalam belajar. Supaya apa yang diinginkan atau cita-cita akan terwujud jika pendidikannya bagus maka apa yang diinginkan bisa tercapai itulah motivasi dari group siswa tersebut.

Sedangkan pada kelas kontrol siswanya hanya cenderung hanya mendengar, mencatat dan mengiat apa saja yang diberihkan oleh guru dan tidaknya interaksi antar siswa dan guru. Sehingga berdampak pada hasil nilai siswa yang tidak bagus, dikarenahkan tidak adanya motivasi belajar sehingga mereka tidak semangat untuk sekolah, tidak datang tepat waktu, bolos, dan di hancurkan lagi mereka tidak adanya motivasi untuk mengejar cita-cita mereka.

Pengujian prasyarat dilakukan dengan analisis uji normalitas dan homogenitas hasilnya diperoleh bahwa data pretest dan posttest berdistribusi normal dan homogen, sehingga dapat dilanjutkan pada pengujian hipotesis menggunakan statistik parametris (uji-t). $t$ hitung lebih besar dari t tabel (6,369 > 
1,683). Berdasarkan hasil analisis data.Ada pengaruh pengaruh motivasi belajar terhadap hasil belajar siswa di SMP YWKA Palembang 2019/2020 diterima.

Penelitian ini juga di dukung oleh wijaya dkk Adanya pengaruh motivasi dapat meningkatkan hasil belajar yang baik untuk merangsang kecerdasaan anak.Dan ada juga Evan dkk pengaruh motivasi dapat meningkatkan hasil belajar pada mata pelajaran gambar teknik.

2. Terdapat Perbedaan Motivasi Belajar Baik Itu Tinggi, Sedang, Rendah, Pada Penelitian Ini

Karena yang telah dilakukan oleh peneliti pada pertemuan pertama siswa mulai memahami materi, pertemuan kedua siswa mulai menunjukan hasil pembelajaran yang hampir mencapai penguasaan materi, dan ketiga siswa mulai menguasai materi pembelajaran yang dimana ditunjukan pada pemberian soal kepada siswa nilai yang didapatkan, pada pertemuan keempat peneliti memberikan angket kepada siswa pada akhir pembelajaran, menunjukan secara keseluruhan bahwa terdapat perbedaan motivasi dan metode ceramah yang tidak diberikan perlakuan.

\section{KESIMPULAN}

Berdasakan hasil penelitian, analisis data, pengujian hipotesis yang dilakukan peneliti serta hasil pembahasan yang didapat, maka dapat disimpulkan bahwa:

1. Ada pengaruh motivasi belajar terhadap hasil belajar siswa di SMP YWKA Palembang 2019/2020 diterima.

2. Ho Terima jika t hitung 6,369 < t tabel 1,683 maka Ha ditolak

\section{DAFTAR PUSTAKA}

Arikunto, Suharsimi. 2016. Prosedur Peneltian, Edisi Revisi 2016. Jakarta: Rineka Cipta.

Afandi, Chamalah, Wardani. 2013. Model dan Metode Pembelajaran di Sekolah.Semarang: Unissula Press.

Budiningsih, Asri. 2005. Belajar dan Pembelajaran. Jakarta: Rineka Cipta.

Dimayanti, Mujiyanto. 2016. Pengaruh Problem Posing dan PBLTerhadap PrestasiBelajar dan Motivasi Belajar Mahasiswa Pendidikan Matematika Jurnal Riset Pendidikan Matematika. Volume 3, No 1, Mei 2016, ISSN: 2356-2684, Online ISSN: 2477-1503. 
Djamarah, 2011. Psikologi Belajar. Jakarta: Rineka Cipta.

Ferdiansyah, M. 2015. Dasar Penelitian Kualitatif. Bogor: Herya Media.

Hamalik. 2013. Proses Belajar Mengajar. Jakarta: Bumi Aksara.

Jihad, Haris. 2013. Evaluasi Belajar. Yogyakarta: Multi Pressindo.

Makmun. 2004. Psikologi Kependidikan. Bandung: Remaja Rosda Karya.

Martinis,Yamin. 2007. Jejak Inovasi Pembelajaran IPS Mengembangkan Profesi Guru.Volume 3, No, 1 April 2015.

Muhdyahardjo, Redja. 2014. Pengantar Pendidikan. Depok: Raja Grafindo.

Nana, Sudjana. 2009. Penilaian Hasil Proses Belajar.Bandung: Remaja Rosda Karya.

Sudjana. 2005. Metode Statistika. Bandung: Tarsito.

Thobroni, M. 2016. Belajar dan Pembelajaran. Depok: Ar-Ruzz Media.

Udin, S. 2007. Peningkatan Hasil Belajar IPA Melalui Metode Demonstrasi Jakarta: Hariyanto.

Purwanto. 2007. Belajar dan Pembelajaran. Jakarta: Rineka Cipta.

Walgito. 2004. Psikologi Kependidikan. Bandung: Remaja Rosda Karya. 